\title{
Impacts of different cytokine and chemokine polymorphisms in Pakistani asthmatics a case control study
}

\author{
Nusrat Saba ${ }^{1 *}$, Ghazala Kaukab Raja ${ }^{2}$, Osman Yusuf ${ }^{3}$, Sadia Rehman ${ }^{1}$, Saeeda Munir ${ }^{1}$ \\ and Atika Mansoor ${ }^{1}$
}

\begin{abstract}
Background: Asthma is a chronic disease of the airways. Its symptoms are caused by inflammation and constriction of the bronchial muscles. During asthma there are changes in immunological pathways in which various cytokines and chemokines are involved directly or indirectly. The present study was conducted to explore the involvement of 15 Single nucleotide polymorphisms (SNPs) in 10 candidate cytokine and chemokine genes with asthma in Pakistani population.
\end{abstract}

Methods: We conducted this study in 333 asthmatic cases and 220 healthy controls.Genotyping was performed using the Sequenom Mass ARRAY iPLEX platform (10 SNPs) and TaqMan assay (5 SNPs).

Results: The minor allele at two SNPs have shown evidence of association with risk for asthma, rs1800896 in the interleukin 10 (IL10) (OR 1.38, 95\% Cl 1.01-1.88, P= 0.04) and rs1800925 in the interleukin 13 (IL13) (OR 1.45, 95\% Cl 1.04-2.02, P=0.03).

Conclusion: Variations at the IL10 and IL13 genes are found to be associated with asthma susceptibility in the Pakistani population.

Keywords: Asthma, Genetic polymorphisms, Pakistan, Asthma association with cytokines

\section{Background}

Asthma is a disease of the lower airways that is remarkably heterogeneous between affected individuals [1]. Asthma symptoms are caused by inflammation, which results in narrowing of the airways, mucous secretion, and are characterized by recurrent attacks of paroxysmal dyspnea, with wheezing due to spasmodic contraction of the bronchi $[2,3]$. Asthma is very common, with approximately $10 \%$ of people in the western world diagnosed with asthma at some stage in their life. The causes of asthma are not fully understood. Both genetic and environmental factors are involved, but how these factors interact to confer risk is still largely unknown.

Many biological pathways, and genes in those pathways, have been implicated in asthma pathogenesis. Variants in over 100 genes have been associated with asthma, but all with small individual effect sizes. It is

* Correspondence: nusratsaba@yahoo.co.in

${ }^{1}$ Institute of Biomedical and Genetic Engineering, G-9/1, Islamabad, Pakistan Full list of author information is available at the end of the article likely that many genes act in concert to determine individual-specific risks for asthma [4]. Genes involved in immunological pathways are important in asthma pathogenesis. Therefore, based on results of previous candidate gene and genome-wide studies, we selected 15 single nucleotide polymorphisms (SNPs) in 10 cytokine and chemokine genes for genotyping in Pakistani asthma cases and controls. The selection of genes is purely rely on the immunological pathways.

\section{Methods \\ Patient population and study design Ethical statement}

The ethical review committee of the parent organization approved this project (ERC-08-01).

\section{Informed consent}

Written informed consent was obtained from all participants. 
Asthmatic subjects were recruited from cities of Islamabad and Lahore of Pakistan. These all subjects belong to ethnic groups from Pakistan. Cases and controls all are from same ethnicity. There are total 533 samples included in the present study in which 333 Pakistani adult subjects were with an asthma diagnosis provided by a pulmonologist. Cases of asthma were selected for sample collection from the outpatient clinics of Rawalpindi, Islamabad and Lahore. Chest specialists based on clinical examination diagnosed the patients. Both patients and controls were from a similar ethnic background, and belonged to various castes and tribes from northern Punjab and the Northwest Frontier Province of Pakistan. Normal subjects, as control, were selected from general healthy population. Two hundred non-asthmatic healthy controls were recruited from the general population to be similar to the cases with respect to ethnicity and proportions of males and females.

Blood sample collection, DNA extraction, and genotyping A venous blood sample was obtained from each study participant, and genomic DNA was extracted from whole blood using a standard phenol chloroform extraction protocol [5]. We selected SNPs in genes that are involved in the immune system and implicated in asthma risk, as reported in previous studies. Ten SNPs were genotyped using a Sequenom iPLEX assay and five SNPs were genotyped using TaqMan assays and analyzed on an ABI 7900 HT Fast Real Time PCR (Applied Biosystems, USA). All genotyping was performed at the University of Chicago USA.

\section{Quality checks and statistical analyses}

Hardy-Weinberg equilibrium (HWE) was determined in the entire sample and separately in the cases and controls. All SNPs were in HWE. Multiple logistic regression was used to estimate odds ratios (ORs) and 95\% confidence intervals (CIs) for each SNP.

\section{Results}

\section{Demographic and genotyping characteristics}

The asthma cases included 148 (44.5\%) males and 185 (55.5\%) females; the mean age was $40 \pm \mathrm{SE}=0.93$ years The controls included 88 males (44.0\%) males and 112 (56.0\%)) females with mean age of $30 \pm \mathrm{SE}=0.97$ years.

Of the 15 SNPs included in our study, all were in Hardy-Weinberg equilibrium. The genotyping methods, call rates, minor allele frequencies, and Hardy-Weinberg $P$-value calculated as a group are shown for all SNPs in Table 1.

\section{Allelic and genotypic associations}

Four SNPs showed evidence for an association with asthma at a $P<0.05$. The allele and genotype frequencies in cases and controls for these four SNPs and results of all analyses are shown in Table 2.

Homozygosity for the minor alleles at SNPs in two other genes, IL10 and IL13, was associated with asthma risk. There were more GG homozygotes at rs1800896 in IL10 in cases compared to controls (recessive risk model $p=0.04$ ) and more TT homozygotes at rs1800925 in IL13in cases compared to controls (recessive risk model, $P=0.009)$.

Table 1 Single Nucleotide Polymorphisms (SNPS) Genotyped in Asthma cases and controls

\begin{tabular}{|c|c|c|c|c|c|c|c|c|}
\hline Gene & Chr location & rs \# & Literature cited (Sup Ref) & Genotyping technique & Call Rate & $\begin{array}{l}\text { Allele } \\
\text { (minor/major) }\end{array}$ & MAF & $\begin{array}{l}\text { HWE } \\
P \text {-value }\end{array}$ \\
\hline IL10 & 1 & rs1800871 & [36-38] & iPLEX & 0.969 & $\mathrm{~T} / \mathrm{C}$ & 0.403 & 0.229 \\
\hline IL10 & 1 & rs1800896 & [36-39] & iPLEX & 0.968 & $\mathrm{G} / \mathrm{A}$ & 0.257 & 0.216 \\
\hline ILIR1 & 2 & rs10173081 & [44] & Taqman & 0.986 & $\mathrm{~T} / \mathrm{C}$ & 0.060 & 0.997 \\
\hline IL13 & 5 & rs1295685 & [42] & iPLEX & 0.969 & $\mathrm{~T} / \mathrm{C}$ & 0.311 & 0.155 \\
\hline 1413 & 5 & rs1800925 & {$[40,42]$} & iPLEX & 0.962 & $\mathrm{~T} / \mathrm{C}$ & 0.215 & 0.382 \\
\hline IL13 & 5 & rs20541 & {$[40,41]$} & iPLEX & 0.960 & $\mathrm{~T} / \mathrm{C}$ & 0.299 & 0.050 \\
\hline TSLP & 5 & rs1837253 & {$[50,51]$} & Taqman & 0.993 & T/C & 0.319 & 0.556 \\
\hline TSLP & 5 & rs2289278 & {$[52,53]$} & Taqman & 0.915 & $\mathrm{G} / \mathrm{C}$ & 0.092 & 0.355 \\
\hline IL33 & 9 & rs1342326 & [43] & iPLEX & 0.969 & $\mathrm{G} / \mathrm{T}$ & 0.165 & 0.090 \\
\hline TLR4 & 9 & rs4986790 & [56] & Taqman & 1.007 & $\mathrm{G} / \mathrm{A}$ & 0.106 & 0.216 \\
\hline CC16 & 11 & rs3741240 & {$[54,55]$} & Taqman & 0.977 & $A / G$ & 0.404 & 0.623 \\
\hline ILARA & 16 & rs1801275 & {$[48,49]$} & iPLEX & 0.971 & $\mathrm{G} / \mathrm{A}$ & 0.201 & 0.246 \\
\hline ILARA & 16 & rs1805011 & {$[42,48]$} & iPLEX & 0.968 & $C / A$ & 0.049 & 0.010 \\
\hline CCL11 & 17 & rs17809012 & [45-47] & iPLEX & 0.957 & $\mathrm{G} / \mathrm{A}$ & 0.454 & 0.615 \\
\hline CCL5 & 17 & rs1800825 & [57] & iPLEX & 0.973 & $C / T$ & 0.030 & 0.432 \\
\hline
\end{tabular}

Literature cited is attached as a separate supplementary references file 
Table 2 Association of Genotype and Allele Frequencies with Asthma Among Cases and Controls

\begin{tabular}{|c|c|c|c|c|c|c|c|c|}
\hline SNP & sample & Minor Allele & $\begin{array}{l}\text { Major } \\
\text { Allele }\end{array}$ & $\begin{array}{l}\text { Homozygotes } \\
\text { Minor }\end{array}$ & Heterozygotes & $\begin{array}{l}\text { Homozygotes } \\
\text { Major }\end{array}$ & odds Ratio & $95 \% \mathrm{Cl}$ \\
\hline & & $\mathrm{T}$ & C & $\pi$ & $C T$ & CC & & \\
\hline \multirow[t]{3}{*}{ rs1800871 } & case & 252 & 396 & 55 & 142 & 127 & 0.81 & $(0.62-1.05)$ \\
\hline & control & 155 & 197 & 33 & 89 & 54 & & \\
\hline & & G & A & GG & $A G$ & AA & & \\
\hline \multirow[t]{3}{*}{ rs1800896 } & case & 179 & 473 & 30 & 119 & 177 & 1.38 & $(1.01-1.88)$ \\
\hline & control & 74 & 270 & 7 & 60 & 105 & & \\
\hline & & $\mathrm{T}$ & C & $\pi$ & $C T$ & CC & & \\
\hline \multirow[t]{3}{*}{ rs10173081 } & case & 36 & 624 & 1 & 34 & 295 & 0.68 & $(0.41-1.14)$ \\
\hline & control & 28 & 332 & 1 & 26 & 153 & & \\
\hline & & $\mathrm{T}$ & C & $\pi$ & $C T$ & $\mathrm{CC}$ & & \\
\hline \multirow[t]{3}{*}{ rs1295685 } & case & 206 & 450 & 36 & 134 & 158 & 1.06 & $(0.80-1.41)$ \\
\hline & control & 103 & 239 & 16 & 71 & 84 & & \\
\hline & & $\mathrm{T}$ & C & $\pi$ & $C T$ & $\mathrm{CC}$ & & \\
\hline \multirow[t]{3}{*}{ rs1800925 } & case & 149 & 497 & 21 & 107 & 195 & 1.45 & $(1.04-2.02)$ \\
\hline & control & 59 & 285 & 3 & 53 & 116 & & \\
\hline & & $\mathrm{T}$ & C & $\pi$ & $C T$ & CC & & \\
\hline \multirow[t]{3}{*}{ rs1837253 } & case & 199 & 455 & 28 & 143 & 156 & 0.85 & $(0.65-1.11)$ \\
\hline & control & 126 & 244 & 20 & 86 & 79 & & \\
\hline & & $\mathrm{T}$ & $C$ & $\pi$ & $C T$ & $C C$ & & \\
\hline \multirow[t]{3}{*}{ rs20541 } & case & 191 & 449 & 35 & 121 & 164 & 0.97 & $(0.73-1.28)$ \\
\hline & control & 107 & 243 & 17 & 73 & 85 & & \\
\hline & & G & C & GG & $C G$ & $\mathrm{CC}$ & & \\
\hline \multirow[t]{3}{*}{ rs2289278 } & case & 54 & 560 & 1 & 52 & 254 & 0.98 & $(0.61-1.56)$ \\
\hline & control & 30 & 304 & 4 & 22 & 141 & & \\
\hline & & G & $\mathrm{T}$ & GG & GT & $\pi$ & & \\
\hline \multirow[t]{3}{*}{ rs1342326 } & case & 104 & 546 & 14 & 76 & 235 & 0.92 & $(0.65-1.30)$ \\
\hline & control & 60 & 290 & 5 & 50 & 120 & & \\
\hline & & G & A & GG & $A G$ & AA & & \\
\hline \multirow[t]{3}{*}{ rs4986790 } & case & 70 & 604 & 7 & 56 & 274 & 0.91 & $(0.60-1.36)$ \\
\hline & control & 42 & 328 & 1 & 40 & 144 & & \\
\hline & & A & G & $\mathrm{AA}$ & $A G$ & GG & & \\
\hline \multirow[t]{3}{*}{ rs3741240 } & case & 259 & 393 & 53 & 153 & 120 & 0.94 & $(0.72-1.22)$ \\
\hline & control & 148 & 210 & 31 & 86 & 62 & & \\
\hline & & G & A & GG & $A G$ & $\mathrm{AA}$ & & \\
\hline \multirow[t]{3}{*}{ rs1801275 } & case & 134 & 522 & 15 & 104 & 209 & 1.08 & $(0.78-1.50)$ \\
\hline & control & 66 & 278 & 10 & 46 & 116 & & \\
\hline & & C & A & $\mathrm{CC}$ & $A C$ & $\mathrm{AA}$ & & \\
\hline \multirow[t]{3}{*}{ rs1805011 } & case & 39 & 605 & 3 & 33 & 286 & 1.68 & $(0.88-3.19)$ \\
\hline & control & 13 & 339 & 1 & 11 & 164 & & \\
\hline & & G & A & GG & $A G$ & AA & & \\
\hline \multirow[t]{2}{*}{ rs17809012 } & case & 298 & 344 & 69 & 160 & 92 & 1.12 & $(0.86-1.46)$ \\
\hline & control & 149 & 193 & 34 & 81 & 56 & & \\
\hline
\end{tabular}


Table 2 Association of Genotype and Allele Frequencies with Asthma Among Cases and Controls (Continued)

\begin{tabular}{|c|c|c|c|c|c|c|c|c|}
\hline SNP & sample & Minor Allele & $\begin{array}{l}\text { Major } \\
\text { Allele }\end{array}$ & $\begin{array}{l}\text { Homozygotes } \\
\text { Minor }\end{array}$ & Heterozygotes & $\begin{array}{l}\text { Homozygotes } \\
\text { Major }\end{array}$ & odds Ratio & $95 \% \mathrm{Cl}$ \\
\hline & & $C$ & T & CC & $\mathrm{CT}$ & TT & & \\
\hline \multirow[t]{2}{*}{ rs1800825 } & case & 22 & 636 & 1 & 20 & 308 & 1.29 & $(0.59-2.83)$ \\
\hline & control & 9 & 335 & 0 & 9 & 163 & & \\
\hline
\end{tabular}

\section{Discussion}

This candidate gene study was conducted in Pakistani asthma patients and healthy controls. This study was carried out to validate in our population various cytokines and chemokines associations with asthma. This is the first study to report associations between these SNPs and asthma in Pakistani population to see the effect of these variations in pathogenesis if we look at the immunological pathways.

In the present study, we investigated the association between 15SNPs in 10 candidate genes (Table 1) for asthma in the Pakistani population. All of the genes included in the present study were either directly or indirectly involved in pathways affecting the immunological process. The lack of very strong associations in our data could be due to the relatively small size of the study sample and the fact that the subjects in our study were adults whereas most of the previous genetic studies were performed largely in children with asthma [3, 6-8]. The present data is a helpful in future genetic studies of adult asthmatics.

Asthma is caused by interaction of multiple genes, some of which have a protective effect and others contribute to the pathogenesis of the disease, with each gene having its own tendency to be influenced by the environment. In asthmatic individuals, antigen presentation is thought to result in the polarization of T-cell differentiation towards a Th2 pattern, whereas T-cells from nonatopic, non-asthmatic individuals show the opposing Th1 (interferon- $\gamma$ and $I L-2$ ) pattern of cytokine secretion [9]. Activated Th2cells secrete cytokines such as $I L-4$, $I L-13$ and $I L-5 . I L-13$ has a pivotal role in asthma pathogenesis: it activates a receptor complex that is composed of the $I L-4 R \alpha$ and $I L-13 R \alpha 1$ on many cell types in the airway wall and is thought to mediate many processes that are relevant to asthma pathology as a result of activation of this receptor complex [10]. Th17 lymphocytes also play a role in the pathogenesis of several autoimmune and inflammatory diseases [11]. Studies have also demonstrated that the proportion of Th17/Th2 cells is extremely low in healthy subjects, whereas their numbers appeared to be significantly higher in the circulation of patients with chronic severe asthma [12].

Homozygosity for the minor alleles at IL13 was associated with asthma risk. There were more TT homozygotes at rs1800925 in IL13in cases compared to controls (recessive risk model, $P=0.009$ ). Interleukin (IL)-13 is a critical mediator in the pathogenesis of allergic inflammation [13]. This cytokine upregulates major histocompatibility complex class II expression and promotes IgEisotype switching. This cytokine is found to be critical to the pathogenesis of allergen-induced asthma but operates through mechanisms independent of IgE [14]. Multiple genetic variants in the promoter $(\mathrm{C}-1112 \mathrm{~T}$ : rs1800925; A-1521C: rs1881457) and coding regions (G2044A: rs20541) have been associated with atopic asthma and non-atopic asthma, increased risk of sensitization to food and outdoor allergens, and bronchial hypersensitiveness in multiple studies $[15,16]$. It has also been reported that the rs1800925 $(-1112 \mathrm{C} / \mathrm{T})$ polymorphism resulted in enhanced promoter activity [17]. In spite of the importance of $I L-13$ in asthma [18-20], some studies failed to show an association between IL13 polymorphisms and asthma phenotypes [21, 22], possibly because of different exposures to environmental risk factors such as tobacco smoke exposure. Beghe [23] reported associations of rs1800925, rs1295685 and rs20541 in IL13 with both atopy and asthma. These are different SNPs which are located in IL13, some or which are not in LD. All three SNPs were included in our study of Pakistani cases and controls, but only rs 1800925 showed evidence of association with asthma. In all studies, including ours, the $\mathrm{T}$ allele was associated with susceptibility. Previous functional study on SNP rs1800925 showed that $-1112 \mathrm{~T}$ allele enhanced IL13 promoter activity in CD4+ Th2 lymphocytes. Increased expression of IL13 -1112 T in Th2 cells was associated with attenuated STAT6-mediated transcription repression [24]. This offers a possible reason for the significant $P$-value for the $\mathrm{T}$ allele of rs18000925 in our Pakistani subject population.

Homozygosity for the minor alleles at SNPs IL10 was associated with asthma risk. There were more GG homozygotes at rs1800896 in IL10 in cases compared to controls (recessive risk model $P=0.04$ ). $I L-10$ is important in immuno-regulation and considered to be an immunosuppressive factor. Low levels of $I L-10$ expression have been reported to play a role inthe pathogenesis of asthma $[25,26]$. In contrast, high levels of $I L-10$ from regulatory T-cells have a protective effect against airway hyperreactivity and inflammation [27]. In our study, we replicated the association between asthma and a SNP (rs1800896) in the promoter region of IL10. This polymorphism conferred susceptibility to 
asthma in East Asians and adult asthmatics [28]. It lies within a putative ETS-like transcription factor binding site, and it has been suggested that a $G$ allele at this position results in higher expression levels of $I L-10$ transcript $[29,30]$.The association with the $G$ allele in the Pakistani population is consistent with results of studies in Indian [31], Egyptian [6] and other populations [32-34], although the opposite allele was reported in a Korean population [35].

\section{Conclusion}

The GG genotype at rs1800896 (IL10) and the TT genotype at rs1800925 (IL13) are susceptibility genotypes for asthma in the Pakistani population. These results are consistent with previous results on Caucasians and other related population. This adds up new information of these cytokines in Pakistani population as this is not reported in our population previously and this data can be helpful infuture prospects of genetic studies in other world. Further functional genomicsstudies on large number of samples will be needed to replicate these associations and determine the influence of these genes on asthma pathogenesis in Pakistani population, and their roles in gene-gene and gene-environment interactions.

\section{Summary at glance}

Asthma is a chronic disease of the airways. Its causes are not understood. Both genetic and environmental factors are involved. In the present study15 SNPs in 10cytokine and chemokine genes were genotyped in Pakistani asthmatic cases and controls. For genotyping the Sequenom Mass ARRAY iPLEX platform and TaqMan assay were used. Polymorphism in IL10 and IL 13 are associated with asthma susceptibility in Pakistani population.

\section{Acknowledgements}

The authors thank Dr. Carole Ober at the University for Chicago for training, providing infrastructure for genotyping, and commenting on this manuscript, Ms. Giaxin Du (University of Chicago) for statistical analysis, Mr. Kevin Ross (University of Chicago) for technical assistance. These studies were supported by a grant from the IRSIP Higher education commission of Pakistan and by NIH grant HL085197 to Dr. Carole Ober at the University of Chicago.

\section{Funding}

The study was funded by Institute of Biomedical and Genetic Engineering.

\section{Availability of data and materials}

Data sharing not applicable to this article as no datasets were generated or analysed during the current study. All the data published here can be reproduced by the corresponding author if asked.

\section{Authors' contributions}

NS carried out the molecular genetic studies, participated in the data analysis and drafted the manuscript. GR participated in the design of the study and supervised all the work done. OY diagnosed the cases of asthma and helped in sample collection of cases and controls. SR participated in the study design and helped to draft the manuscript. SM participated in the design of the study and helped in molecular genetic studies. AM participated in the design of the study and guided in the statistical analysis. All authors read and approved the final manuscript.

\section{Ethics approval and consent to participate}

The ethical review committee of the parent organization approved this project (ERC-08-01). Written informed consent was obtained from all participants.

\section{Consent for publication}

Informed consent for publication was obtained from all participants.

Competing interests

All authors declare that they have no competing interests.

\section{Publisher's Note}

Springer Nature remains neutral with regard to jurisdictional claims in published maps and institutional affiliations.

\section{Author details \\ ${ }^{1}$ Institute of Biomedical and Genetic Engineering, G-9/1, Islamabad, Pakistan. ${ }^{2}$ Department of Biochemistry, PirMehar Ali Shah Arid Agriculture University Rawalpindi, Rawalpindi, Pakistan. ${ }^{3}$ The Allergy and Asthma Institute of Pakistan, 275, Gomal Road, E-7, Islamabad, Pakistan.}

Received: 14 July 2017 Accepted: 15 November 2017

Published online: 29 November 2017

\section{References}

1. Ober C, Yao TC. The genetics of asthma and allergic disease: a 21st century perspective. Immunol Rev. 2011;242(1):10-30.

2. Holgate ST. Asthma: a simple concept but in reality a complex disease. Eur J Clin Investig. 2011:41:1339-52.

3. Kang SH, Kim HY, Seo JH, Kwon JW, Jung YH, Song YH, Hong SJ. Bronchial hyperresponsiveness to methacholine and AMP in children with atopic asthma. Allergy Asthma Immunol Res. 2012;4(6):341-5.

4. Nicolae $\mathrm{DL}$, Ober C. (too) great expectations: the challenges in replicating asthma disease genes. Am J Respir Crit Care Med. 2009;179:1078-9.

5. Sambrook J, MacCallum P, Russell D. Molecular cloning: a laboratory manual. Third edition. Dallas: Cold Spring Harbor Laboratory Press; 2000.

6. Hussein YM, Shalaby SM, Mohamed RH, Hassan TH. Association between genes encoding components of the $/ L-10 / / L-10$ receptor pathway and asthma in children. Ann Allergy Asthma Immunol. 2011;106(6):474-80.

7. Takeuchi K, Mashimo $Y$, Shimojo N, Arima T, Inoue $Y$, Morita $Y$, Sato K, Suzuki S, Nishimuta T, Watanabe H, Hoshioka A, Tomiita M, Yamaide A, Watanabe M, Okamoto Y, Kohno Y, Hata A, Suzuki Y. Functional variants in the thromboxane $A 2$ receptor gene are associated with lung function in childhood-onset asthma. Clin Exp Allergy. 2013:43(4):413-24.

8. Al-Khayyat Al, Al-Anazi M, Warsy A, Vazquez-Tello A, Alamri AM, Halwani R, Alangari A, Al-Frayh A, Hamid Q, Al-Muhsen S. T1 and T2 ADAM33 single nucleotide polymorphisms and the risk of childhood asthma in a Saudi Arabian population: a pilot study. Ann Saudi Med. 2012;32(5):479-86.

9. Panina-Bordignon P, Papi A, Mariani M, Di Lucia P, Casoni G, Bellettato C, Buonsanti C, Miotto D, Mapp C, Villa A, Arrigoni G, Fabbri LM, Sinigaglia $F$. The C-C chemokine receptors CCR4 and CCR8 identify airway $T$ cells of allergen-challenged atopic asthmatics. J Clin Invest. 2001;107:1357-64

10. Wills-Karp M, Ewart SL. Time to draw breath: asthma-susceptibility genes are identified. Nat Rev Genet. 2004:5:376-87.

11. Oukka M. Th17 cells in immunity and autoimmunity. Ann Rheum Dis. 2008; 67(Suppl 3):26-9.

12. Cosmi L, Liotta F, Maggi E, Romagnani S, Annunziato F. Th17 cells: new players in asthma pathogenesis. Allergy. 2011 Aug;66(8):989-98.

13. Hershey GK. IL-13 receptors and signaling pathways: an evolving web. J Allergy Clin Immunol. 2003;111:677-90.

14. Leonardo A, Stein PRT, Kabesch M. Impact of genetics in childhood asthma. J Pediatr. 2008;84(4Suppl):S68-75.

15. Liu X, Beaty TH, Deindl P, Huang SK, Lau S, Sommerfeld C, Fallin MD, Kao WH, Wahn U, Nickel R. Associations between specific serum IgE response and 6 variants within the genes IL4, IL13, and IL4RA in German children: the German multicenter Atopy study. J Allergy Clin Immunol. 2004;113:489-95. 
16. Hummelshoj T, Bodtger U, Datta P, Malling HJ, Oturai A, Poulsen LK, Ryder LP, Sorensen PS, Svejgaard E, Svejgaard A. Association between an interleukin-13 promoter polymorphism and atopy. Eur J Immunol Genet. 2003:30:355-9.

17. Vladich FD, Brazille SM, Stern D, Peck ML, Ghittoni R, Vercelli D. IL-13 R130Q, a common variant associated with allergy and asthma, enhances effector mechanisms essential for human allergic inflammation. J Clin Invest. 2005; 115(3):747-54

18. Wills-Karp M, Luyimbazi J, Xu X, Schofield B, Neben TY, Karp CL, Donaldson DD. Interleukin-13: central mediator of allergic asthma. Science (New York, NY). 1998;282(5397):2258-61.

19. Noakes PS, Holt PG, Prescott SL. Maternal smoking in pregnancy alters neonatal cytokine responses. Allergy. 2003;58(10):1053-8.

20. Feleszko W, Zawadzka-Krajewska A, Matysiak K, Lewandowska D, Peradzynska J, Dinh QT, Hamelmann E, Groneberg DA, Kulus M. Parental tobacco smoking is associated with augmented IL-13 secretion in children with allergic asthma. J Allergy Clin Immunol. 2006;117(1):97-102.

21. Leung TF, Tang NL, Chan IH, Li AM, Ha G, Lam CW. A polymorphism in the coding region of interleukin-13 gene is associated with atopy but not asthma in Chinese children. Clin Exp Allergy. 2001;31(10):1515-21.

22. Hakonarson H, Wist M. Current concepts on the genetics of asthma. Current Opin Pediat. 2001;13(3):267-77.

23. Beghé B, Hall IP, Parker SG, Moffatt MF, Wardlaw A, Connolly MJ, Fabbri LM, Ruse C, Sayers I. Polymorphisms in IL13 pathway genes in asthma and chronic obstructive pulmonary disease. Allergy. 2010;65(4):474-81.

24. Cameron L, Webster RB, Strempel JM, Kiesler P, Kabesch M, Ramachandran H, Yu L, Stern DA, Graves PE, Lohman IC, Wright AL, Halonen M, Klimecki WT, Vercelli D. Th2 cell-selective enhancement of human IL13 transcription by IL13-1112C $>$ T, a polymorphism associated with allergic inflammation. J Immunol. 2006:177:8633-42.

25. Makela MJ, Kanehiro A, Borish L, Dakhama A, Loader J, Joetham A, Xing Z, Jordana M, Larsen GL, Gelfand EW. IL-10 is necessary for the expression of airway hyperresponsiveness but not pulmonary inflammation after allergic sensitization. Proc Natl Acad Sci U S A. 2000;97:6007-12.

26. Tarzi M, Klunker S, Texier C, Verhoef A, Stapel SO, Akdis CA, Maillere B, Kay $A B$, Larché $M$. Induction of interleukin-10 and suppressor of cytokine signalling-3 gene expression following peptide immunotherapy. Clin Exp Allergy. 2006;36:465-74.

27. Stampfli MR, Cwiartka M, Gajewska BU, Alvarez D, Ritz SA, Inman MD, Xing Z, Jordana M. Interleukin-10 gene transfer to the airway regulates allergic mucosal sensitization in mice. Am J Respir Cell Mol Biol. 1999; 21:586-96.

28. Hyun MH, Lee $\mathrm{CH}$, Kang MH, Park BK, Lee YH. Interleukin-10 promoter gene polymorphisms and susceptibility to asthma: a meta-analysis. PLoS One. 2013:8(1):e53758.

29. Mormann M, Rieth H, Hua TD, Assohou C, Roupelieva M, Hu SL, Kremsner PG, Luty AJ, Kube D. Mosaics of gene variations in the Interleukin-10 gene promoter affect interleukin-10 production depending on the stimulation used. Genes Immun. 2004:5:246-55.

30. Gruber SG, Gloria Luciani M, Grundtner P, Zdanov A, Gasche C. Differential signaling of $\mathrm{cmvlL}-10$ through common variants of the IL-10 receptor 1. Eur J Immunol. 2008;38:3365-75.

31. Chatterjee R, Batra J, Kumar A, Mabalirajan U, Nahid S, Niphadkar PV, Ghosh B. Interleukin-10 promoter polymorphisms and atopic asthma in north Indians. Clin Exp Allergy. 2005;35(7):914-9.

32. Chung F, et al. Mediat Inflamm. 2001;10:51-9.

33. Asadullah K, Sterry W, Volk HD. Interleukin-10 therapy—review of a new approach. Pharmacol Rev. 2003;55(2):241-69.

34. Barnes PJ. Cytokine modulators as novel therapies for asthma. Ann Rev Pharmacol Toxicol. 2002:42:81-98.

35. Park BL, Kim LH, Choi YH, Lee JH, Rhim T, Lee YM, Uh ST, Park HS, Choi BW, Hong SJ, Park CS, Shin HD. Interleukin 3 (IL3) polymorphisms associated with decreased risk of asthma and atopy. J Hum Genet. 2004:49(10):517-27.

36. Kim KW, Lee KE, Hong JY, Kim MN, Heo WI, Sohn MH, Kim KE. Involvement of $1 L-10$ gene promoter polymorphisms in the susceptibility for childhood asthma. Lung. 2011;189(5):417-23.

37. Trajkov D, Mirkovska-Stojkovikj J, Arsov T, Petlichkovski A, Strezova A, Efinska-Mladenovska O, Sandevska E, Gogusev J, Spiroski M. Association of cytokine gene polymorphisms with bronchial asthma in Macedonians. Iran J Allergy Asthma Immunol. 2008;7(3):143-56.
38. Movahedi M, Mahdaviani SA, Rezaei N, Moradi B, Dorkhosh S, Amirzargar AA. IL-10, TGF-beta, IL-2, IL-12, and IFN-gamma cytokine gene polymorphisms in asthma. J Asthma. 2008:45(9):790-4.

39. Zedan M, Settin A, Farag MK, El-Bayoumi M, El Regal ME, El Baz R, Osman E. Gene polymorphisms of tumor necrosis factor alpha-308 and interleukin-10-1082 among asthmatic Egyptian children. Allergy Asthma Proc. 2008;29(3):268-73.

40. Miyake Y, Tanaka K, Arakawa M. IL13 genetic polymorphisms, smoking, and eczema in women: a case-control study in Japan. BMC Med Genet. 2011;12:142.

41. Yang XX, Li FX, Wu YS, Wu D, Tan JY, Li M. Association of TGF-betal, IL-4 and IL-13 gene polymerphisms with asthma in a Chinese population. Asian Pac J Allergy Immunol. 2011;29(3):273-7.

42. Bottema RW, Nolte IM, Howard TD, Koppelman GH, Dubois AE, de Meer G, Kerkhof M, Bleecker ER, Meyers DA, Postma DS. Interleukin 13 and interleukin 4 receptor-a polymorphisms in rhinitis and asthma. Int Arch Allergy Immunol. 2010;153(3):259-67.

43. Moffatt MF, Gut IG, Demenais F, Strachan DP, Bouzigon E, Heath S, von Mutius E, Farrall M, Lathrop M, Cookson WO, GABRIEL Consortium. A large-scale, consortium-based genomewide association study of asthma. N Engl J Med. 2010;363(13):1211-21.

44. Torgerson DG, Ampleford EJ, Chiu GY, Gauderman WJ, Gignoux CR, Graves PE, Himes BE, Levin AM, Mathias RA, Hancock DB, Baurley JW, Eng C, Stern DA, Celedón JC, Rafaels N, et al. Meta-analysis of genome-wide association studies of asthma in ethnically diverse north American populations. Nat Genet. 2011;43(9):887-92.

45. Chang HS, Kim JS, Lee JH, Cho JI, Rhim TY, Uh ST, Park BL, Chung IY, Park CS, Shin HD. A single nucleotide polymorphism on the promoter of eotaxin 1 associates with its mRNA expression and asthma phenotypes. J Immunol. 2005;174(3):1525-31.

46. Raby BA, Van Steen K, Lazarus R, Celedon JC, Silverman EK, Weiss ST. Eotaxin polymorphisms and serum total lgE levels in children with asthma. J Allergy Clin Immunol. 2006;117:298-305.

47. Tsunemi Y, Saeki H, Nakamura K, Sekiya T, Hirai K, Fujita H, Asano N, Tanida Y, Kakinuma T, Wakugawa M, Torii H, Tamaki K. Eotaxin gene single nucleotide polymorphisms in the promoter and exon regions are not associated with susceptibility to atopic dermatitis, but two of them in the promoter region are associated with serum lgE levels in patients with atopic dermatitis. J Dermatol Sci. 2002;29(3):222-8.

48. Miyake Y, Tanaka K, Arakawa M. Case-control study of eczema in relation to IL4Ra genetic polymorphisms in Japanese women: the Kyushu Okinawa maternal and child health study. Scand J Immunol. 2013;77(5):413-8.

49. Murk W, Walsh K, Hsu LI, Zhao L, Bracken MB, Dewan AT. Attempted replication of 50 reported asthma risk genes identifies a SNP in RAD50 as associated with childhood atopic asthma. Hum Hered. 2011;71(2):97-105.

50. Bunyavanich S, Melen E, Wilk JB, Granada M, Soto-Quiros ME, Avila L, Lasky-Su J, Hunninghake GM, Wickman M, Pershagen G, O'Connor GT, Weiss ST, Celedón JC. Thymic stromal lymphopoietin (TSLP) is associated with allergic rhinitis in children with asthma. Clin Mol Allergy. 2011;9:1.

51. Hunninghake GM, Soto-Quirós ME, Avila L, Kim HP, Lasky-Su J, Rafaels N Ruczinski I, Beaty TH, Mathias RA, Barnes KC, Wilk JB, O'Connor GT, Gauderman WJ, Vora H, Baurley JW, et al. TSLP polymorphisms are associated with asthma in a sex-specific fashion. Allergy. 2010;65(12):1566-75.

52. Harada M, Hirota T, Jodo Al, Hitomi Y, Sakashita M, Tsunoda T, Miyagawa T, Doi S, Kameda M, Fujita K, Miyatake A, Enomoto T, Noguchi E, Masuko H, Sakamoto T, et al. Thymic stromal lymphopoietin gene promoter polymorphisms are associated with susceptibility to bronchial asthma. Am J Respir Cell Mol Biol 2011; 44(6):787-793.

53 Liu W, Xu LS, Liu QJ, Dong FZ, Qiu RF, Wen MC, Han YL, Tang NB, Kang L, Wu JX, Liu F, Zhao JP, Yang MM, Wang JF, Ding MJ, et al. Two single nucleotide polymorphisms in TSLP gene are associated with asthma susceptibility in Chinese Han population. Exp Lung Res. 2012;38(8):375-82.

54. Ku MS, Sun HL, Lu KH, Sheu JN, Lee HS, Yang SF, Lue KH. The CC16 A38G polymorphism is associated with the development of asthma in children with allergic rhinitis. Clin Exp Allergy. 2011;41(6):794-800.

55. Laing IA, de Klerk NH, Turner SW, Judge PK, Hayden CM, Landau LI, Goldblatt J. Le Souëf PN; Perth infant asthma follow-up cohort. Cross-sectional and longitudinal association of the secretoglobin 1A1 gene A38G polymorphism with asthma phenotype in the Perth infant asthma follow-up cohort. Clin Exp Allergy. 2009;39(1):62-71.

56 Wagner J, Skinner NA, Catto-Smith AG, Cameron DJ, Michalski WP, Visvanathan K, Kirkwood CD. TLR4, IL1ORA, and NOD2 mutation in paediatric 
Crohn's disease patients: an association with Mycobacterium Avium subspecies paratuberculosis and TLR4 and IL10RA expression. Med Microbiol Immunol. 2013 Mar;2

57. Kim DH, Jung HD, Lee NY, Sohn SK. Single nucleotide polymorphism of CC chemokine ligand 5 promoter gene in recipients may predict the risk of chronic graft-versus-host disease and its severity after allogeneic transplantation. Transplantation. 2007;84(7):917-25.

Submit your next manuscript to BioMed Central and we will help you at every step:

- We accept pre-submission inquiries

- Our selector tool helps you to find the most relevant journal

- We provide round the clock customer support

- Convenient online submission

- Thorough peer review

- Inclusion in PubMed and all major indexing services

- Maximum visibility for your research

Submit your manuscript at www.biomedcentral.com/submit
Biomed Central 